\title{
PALEOENVIRONMENT OF THE DEVONIAN FOSSILIFEROUS GLENERIE LIMESTONE, ROSENDALE, UPSTATE NEW YORK
}

GININDZA, Gugu, Geology Discipline, Earth and Physical Sciences, York College-CUNY, Geology, 94-20 Guy R. Brewer Blvd, Jamaica, NY 11451-0000, FORDE, B’jorn K., Geology Discipline, Earth and Physical Sciences, York College-CUNY, Geology, 94-20 Guy R. Brewer Blvd, AC-2F09, Jamaica, NY 11451, AGUSTIN, Sebastian R., Geology Discipline, York CollegeCUNY, 94-20 Guy R. Brewer Blvd, Jamaica, NY 11451, KHANDAKER, Nazrul I., Earth and Physical Sciences Department - Geology Discipline, York College-CUNY, 94-20 Guy R. Brewer Blvd, AC-2F09, Jamaica, NY 11451, SHAMI, Malek, Geology Discipline, Earth and Physical Sciences, York College Of CUNY, 94-20 Guy R. Brewer Blvd, Jamaica, NY 11451 and SCHLEIFER, Stanley, Earth and Physical Sciences, York College (CUNY), Geology Discipline, AC-2F09, 94-20 Guy R. Brewer Blvd, Jamaica, NY 11451

Abstract

The Devonian Glenerie limestone outcrops throughout the Hudson Valley and is believed to correlate with the glauconite-rich Oriskany sandstone elsewhere in upstate New York. Field inspection of well-preserved outcrops in Rosendale, upstate New York, indicated the Glenerie formation to be composed of both thin and thickly-bedded chert, interbedded shale, and both calcareous to arenaceous limestone. The Glenerie formation is dominated by spirifer arenosis fossil, which is the index fossil for this formation. The goal of this research is to determine the conditions of the paleoenvironment prevalent to the deposition of the Glenerie forme the Within the arenaceous layers are the Spirfer arenosis, Repsela which are sello the were depers are gically affected by weat the lithology of the area of focus, the inter-lake area of Rosendale, New York, encompasse formations of sedimentary strata ranging from Ordovician to the Devonian periods. The interlake area is severely faulted and folded, resulting from the continents of Europe and North America colliding. The Glenerie formation is bordered by the Port Ewen limestone to the east, and the Esopus shale to the west. The lithological and faunal content of the Glenerie formation changed as the depositional environment transitioned from shallow to deep water setting. The fossils indicated organisms with thick shells and presumably provided protection from being winnowed away in a shallow high energy marine environment. The preserved fossil record, along with bedded chert in the Glenerie formation suggest fluctuation in sea level followed by rapid burial of organism

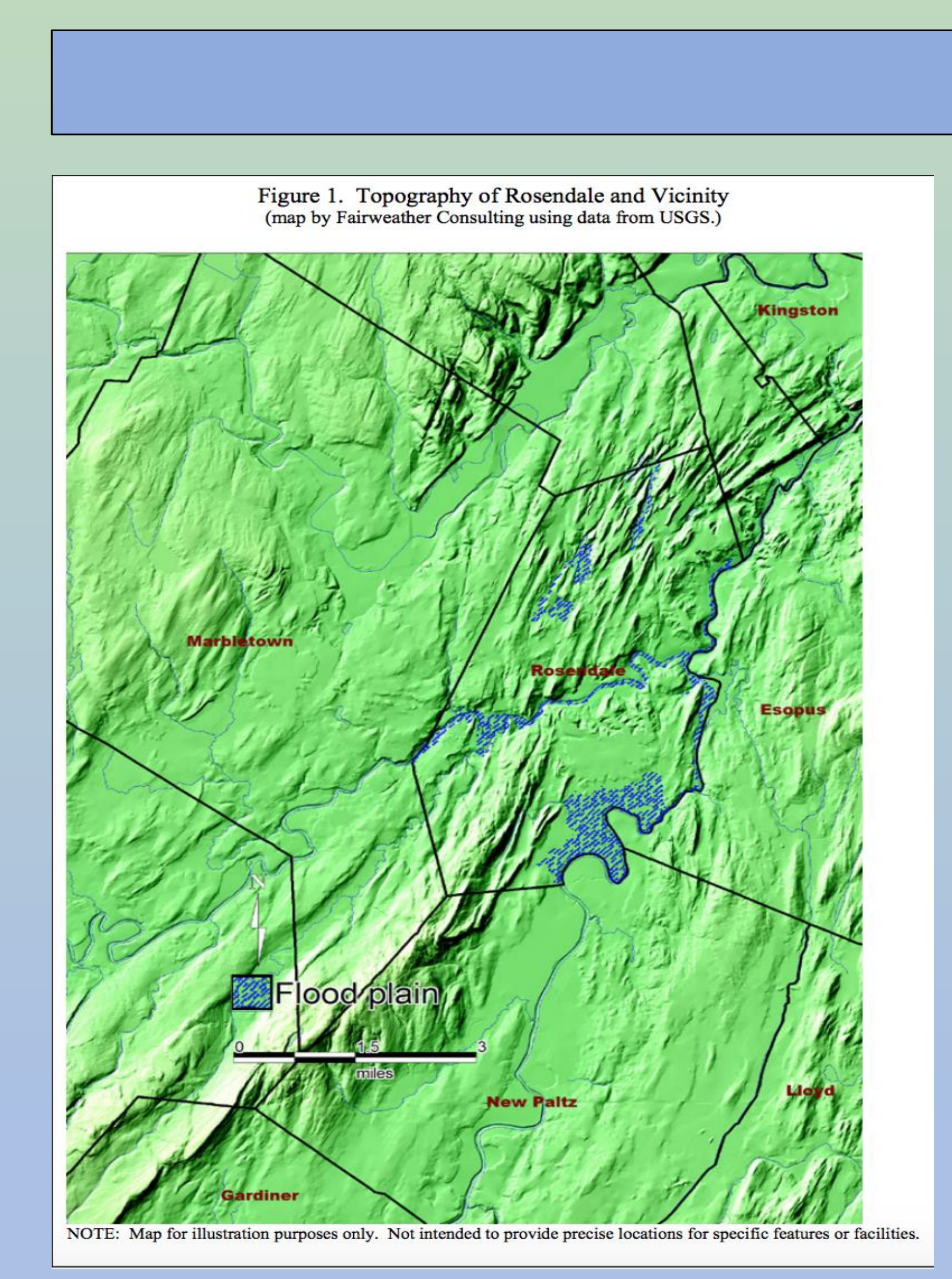

Figure 1. The town of Rosendale, as depicted in a Google image, is located upstate New York in Ulster County, approximately 100 miles North of New York City. The geological coordinates are Latitude: $41.85 \mathrm{~N}$, Longitude: $74.08 \mathrm{~W}$ (Rosendale, New York., n.d.). The town was once known for its high grade cement, but today is sought after for its sophisticated Paleozoic geology.

yeskcollege nationaleríd

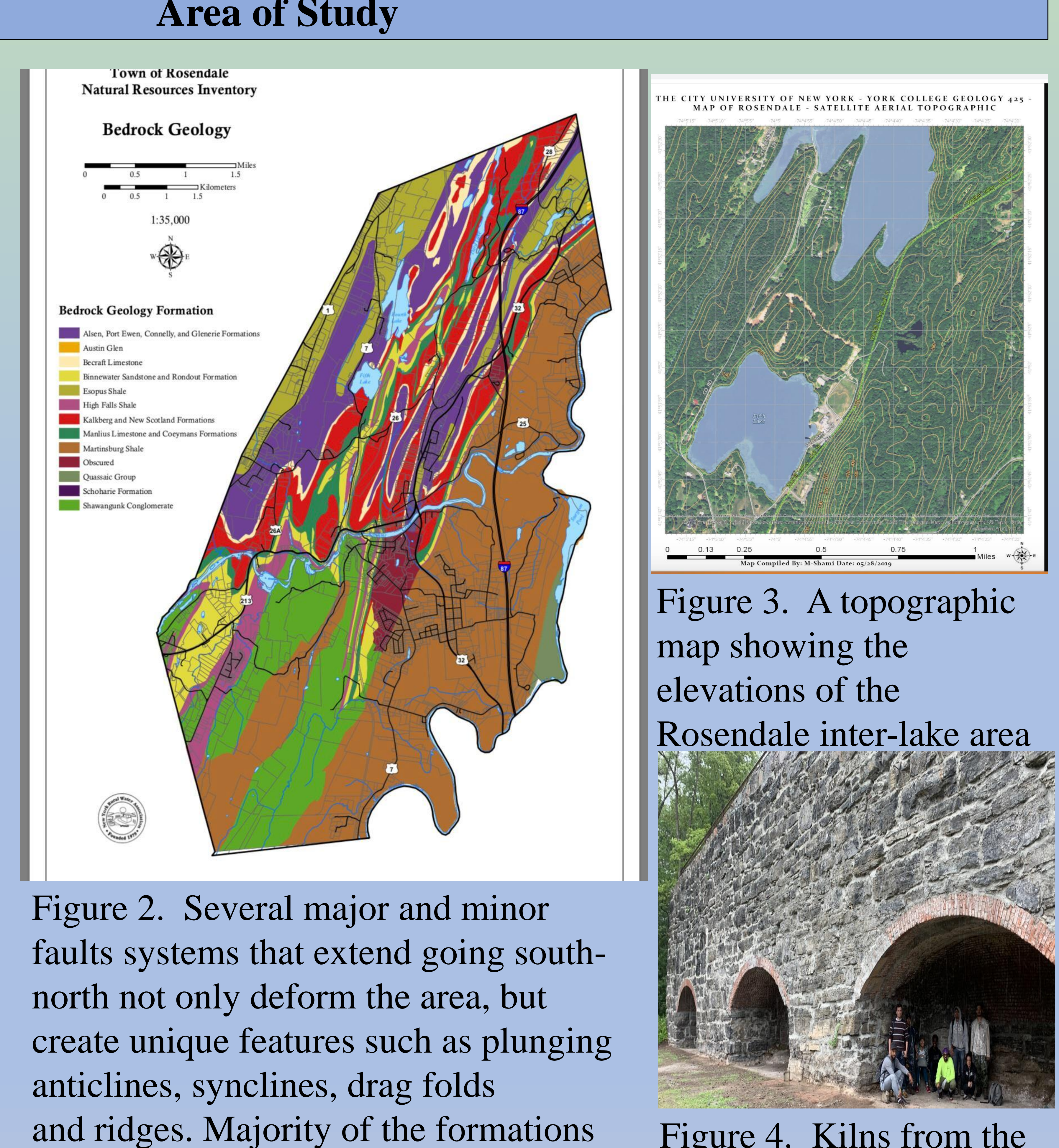
and ridges. Majority of the formations Figure 4. Kilns from the are deep underground with the exception old cement mines in of a few out-crops that allow geologist to Rosendale. project and identify each formation.

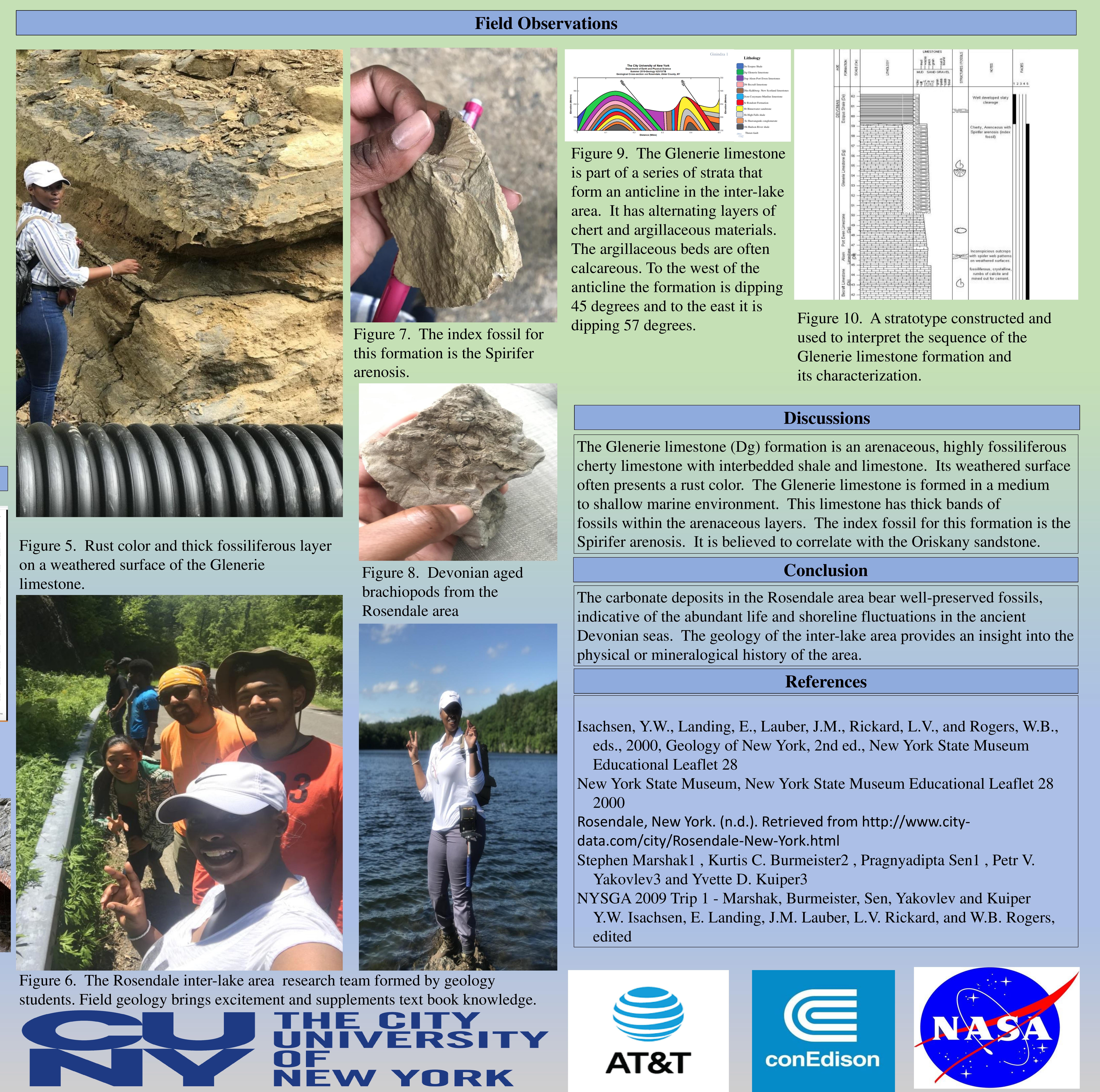

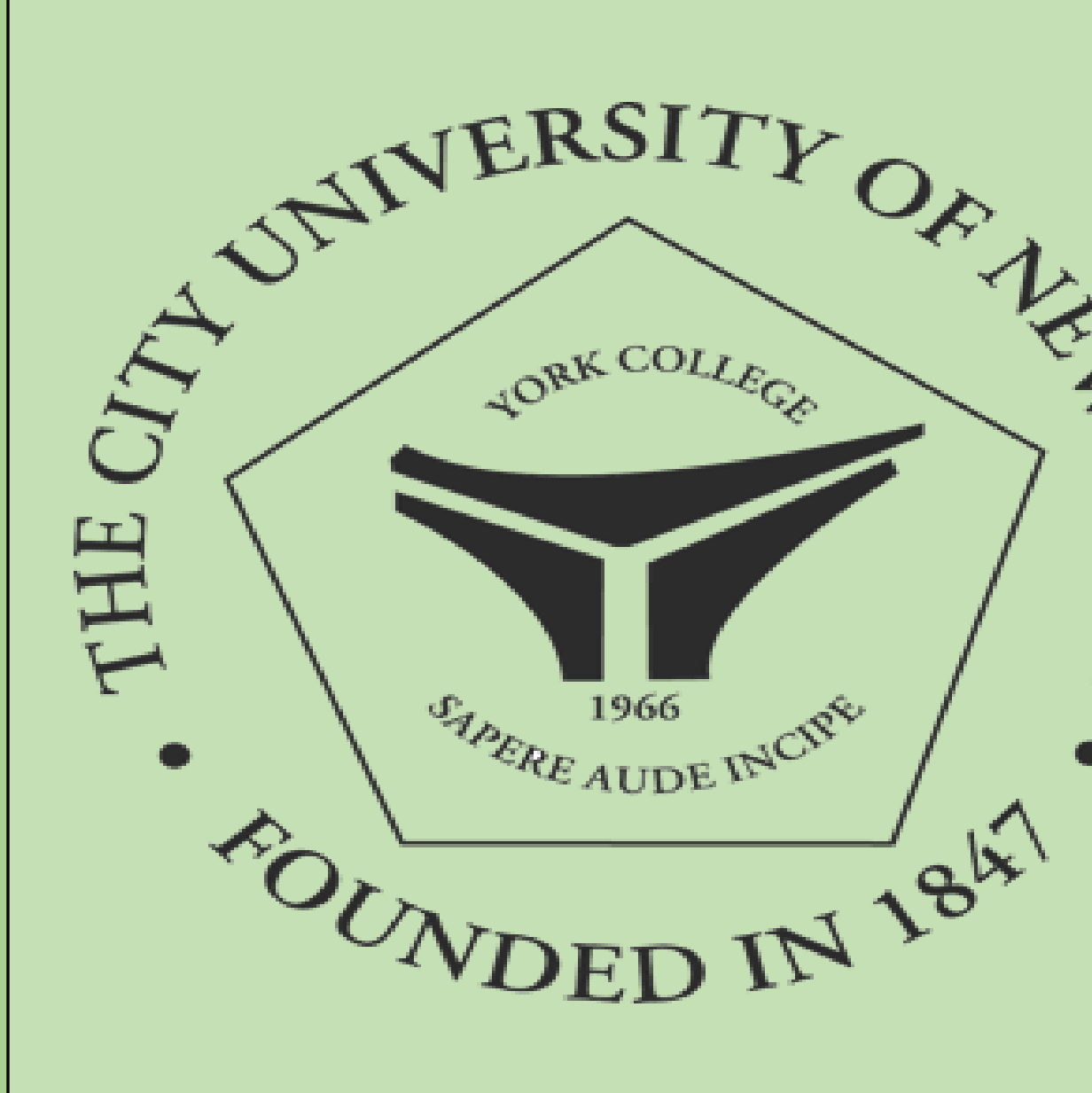

